\title{
Editor's introduction. Qualitative Research in Medicine and Healthcare: The (politics of) the illness experience
}

\author{
Mariaelena Bartesaghi \\ University of South Florida, Tampa, Florida
}

I have no doubt that the ongoing COVID-19 pandemic has made us "nicer", 1 more compassionate, and aware of the suffering of others. It has forced our eyes open to the many preexisting social injustices that we had managed to ignore or push to the side, and the dire need for dramatic changes to social inequalities that perhaps before now we could say did not concern us. The human tragedy of COVID-19 (which is the subject of our next special issue guest edited by physician, author and poet Lodovico Balducci) has connected our bodies to other bodies notwithstanding the mandates of social distancing. It is no accident that the righteous rage of Black Lives Matter over the brutal violence inflicted over decades by the state on people of color overlapped the images of physical wreckage of coronavirus. Both speak to what Foucault understood in terms of biopower, "a power to foster life or disallow it to the point of death", ${ }^{2}$ or the ultimate political sovereignty. Such is the power of healthcare in the United States, I would argue, inasmuch as bodies are classified, measured, assessed, enabled and constrained by the politics of health and illness. For, as Susan Sontag ${ }^{3}$ called attention when discussing cancer and HIV-AIDS, illness is political through and through. During her time as a cancer patient, Sontag found that her body had become metaphor, a cultural and historical site of signification for cancer as a matter of moral failure, defect and shaming, social interaction and stigma beyond any notion of neutral medical treatment. By way of careful qualitative approaches, the

Correspondence: Mariaelena Bartesaghi, Associate Professor, Communication, University of South Florida CIS 1040, 4202 E. Fowler Ave, Tampa, FL 33620, USA; Editor-in-Chief, Qualitative Research in Medicine and Healthcare.

E-mail: mbartesaghi@usf.edu

Received for publication: 22 February 2021.

Accepted for publication: 22 February 2021.

This work is licensed under a Creative Commons Attribution NonCommercial 4.0 License (CC BY-NC 4.0).

${ }^{\circ}$ Copyright: the Author(s), 2020

Licensee PAGEPress, Italy

Qualitative Research in Medicine \& Healthcare 2020; 4:V-VI

doi:10.4081/qrmh.2020.9700 four articles in this issue research the experience of illness, its creation in healthcare dynamics and how research can act as a warrant for the social validation of the illness experience as situated corporeal narration, speaking truth to biopower. What the authors examine are not crises in the sense of experiences that make the news, but as everyday tragedies of bodies in "extreme distress or sorrow": chronic and degenerative illness, end of life decisions, the burden of treatment, and the pitfalls of physical pain

In Living with Parkinson's disease and connected to the duodopa pump,${ }^{5}$ Chacón Gámez and Andorno note that we are living longer with chronic conditions, like Parkinson's Disease (PD) terminal conditions, and that these conditions are liminalities that exist beyond language. While the pump is a technology that manages the disease, the authors examine the experience of PD as it is mediated multimodally, ${ }^{6}$ in both narrative interviews and drawings of newly diagnosed patients. We find that the drawings are signifiers by signifying bodies about the body, its affective tensions and physical sensations, represented by changing colors and lines. Much like the images of schizophrenia drawn by those diagnosed by the condition, ${ }^{7}$ the drawings of PD patients allow an understanding of the transformative complexities of the illness experience.

Moving to another difficult aspect of illness, in Care workers' experiences discussing financial issues with families facing end-of-life decisions Hopeck $^{8}$ studies the accounts of families and care workers -nurses, patient advocates, social workers, and clergy — about how to "afford" terminal care for their loved ones. This term has a double meaning, for finances and emotions are enmeshed in the biopower of healthcare. In a jarring confession, a family member tells of the double bind of keeping their loved one alive to retain their social security payment that would be necessary to afford a costly funeral. When time and money are running out, life and death are equally precious, and yet ironically a matter of tragic calculation. Hopeck's work inscribes the healthcare debates upon our bodies.

In It's long-term, well it's for life basically: Understanding and exploring the burden of immunoglobulin treatment in patients with primary immunodeficiency disorders ${ }^{9}$ Jones and her colleagues attach the term "burden" to what they aptly call "the work of being a patient" (p. 118). ${ }^{9}$ As a chronic condition, immunodeficiencies require 
constant watchfulness, which the pandemic has at least allowed the rest of us to appreciate. Though immuglobin treatment is available, receiving it is a mixed bag of gratitude and commitment on the part of patients. As someone with a chronic and disabling condition, this is something I can understand, and is in fact captured by the oxymoron "pain management." Chronic pain is, in fact, unmanageable, and management often requires that one go on disability, to have the time to devote to its management.

As Graboska and her co-researchers aptly claim, pain is a problem. And it is a political problem. An ethnographic study of opioid use disorder in rural Maine: The problem of pain,,$^{10}$ is an examination of patient experiences with suffering. ${ }^{11,12}$ This suffering is sensate, in the sinews of the body, but it is also affective the matter of medical stigma, and the biopolitics of criminalization of Opioid Use Disorder (OUD). Most physicians do not understand chronic pain past addiction to opioids, and the prescription of suboxone to treat both addiction and pain. Though I have tried suboxone for pain, it did not work for me; it almost killed me. This is because I did not, in fact, have OUD to the point that I could tolerate suboxone. The irony! Though OUD is decriminalized in the United States, the stigma of a suboxone prescription remains, and for many, like me, opioids barely touch pain. Studies like this that listen to the actual experience of patients can open those who treat pain to understand the complexities of pain and the multifaceted pain of those who suffer.

I am a character in one of those small tragedies and my everyday story is one about the burdens of being a patient as well as a human being who suffers. Because of this, I am no longer able to be the Editor-in-Chief of this wonderful journal. Another body will continue my work, your work, the work of Qualitative Research in Medicine and Healthcare in examining, validating, and ultimately speaking of the experiences of those in these pages.

\section{References}

1. Moffitt M. Is the COVID-19 pandemic making us nicer? Signs of civility in Pacifica, SFGATE, April 13; 2020. Available form: https://www.sfgate.com/local/article/Is-theCOVID-19-pandemic-making-us-nicer-Signs-15193385.php

2. Foucault M. Part Five: Right of Death and Power over Life. In The History of Sexuality Volume 1: An Introduction. Trans. Robert Hurley. New York: Vintage Books; 1990: p. 38 .

3. Sontag S. Illness as Metaphor \& AIDS and its Metaphors. Picador; 2001.

4. Oxford Dictionary. Available from: https://www.lexico.com/ en/definition/tragic

5. Chacón Gámez YM, Andorno NB. Living with Parkinson's disease and connected to the duodopa pump: A qualitative study. Qual Res Med Healthcare 2020;4:95-106.

6. Jewitt C. Routledge Handbook of Multimodal Analysis. $2^{\text {nd }}$ Ed. Routledge; 2016.

7. Barnes S. Artistic Teen Illustrates Her Hallucinations to Cope with Schizophrenia. MyModern Met; 2017. Avaible from: https://mymodernmet.com/schizophrenia-drawings/

8. Hopeck P. Care workers' experiences discussing financial issues with families facing end-of-life decisions. Qual Res Med Healthcare 2020;4:107-116.

9. Jones GL, Hajdukova EB, Hanna E, et al. It's long-term, well it's for life basically: Understanding and exploring the burden of immunoglobulin treatment in patients with primary immunodeficiency disorders. Qual Res Med Healthcare 2020;4:117-131.

10. Grabowska W, Holden S, Wayne PM, Kilgore K. An ethnographic study of opioid use disorder in rural Maine: The problem of pain. Qual Res Med Healthcare 2020;4:132.145.

11. Scarry E. The body in pain: The making and unmaking of the world. New York: Oxford University Press; 1985.

12. van Ommen C, Cromby J, Yen J. The contemporary making and unmaking of Elaine Scarry's The Body in Pain. Subjectivity 2016;9:333-42. 